\title{
"Leys da história", "estilo claro", "ordem e sucessão das cousas" na História do Futuro do Padre Antônio Vieira
}

\author{
Jaqueson Luiz da Silva
}

No decurso dos anos de 1662 e 1667, o jesuíta português Antônio Vieira é processado pelo Santo Ofício devido à composição da carta Esperanças de Portugal. Para se defender, compõe papéis que ficaram conhecidos como sua obra profética: História do Futuro, Livro Anteprimeiro da História do Futuro, Apologia das coisas profetizadas, Defesa perante o tribunal do Santo Ofício e Defesa do papel intitulado Quinto Império. A despeito de ser o Livro Anteprimeiro composto posteriormente à História do Futuro e à Apologia das coisas profetizadas, e, diferente destas, não ter sido entregue como defesa na mesa da Inquisição, trabalharemos neste estudo sobretudo com ele porque, como o mesmo Vieira diz no título, é o "prologomeno a toda a Historia do Futuro, em que declara o fim e se provaõ os fundamentos della”.

Para iniciarmos nossas considerações a respeito dos aspectos de história da História do Futuro e do Livro Anteprimeiro, principalmente a respeito da noção de história aí presente, consideramos necessário irmos até os interrogatórios. No terceiro exame dos autos, como já se sabe, Alexandre da Silva argúi Vieira a respeito de ter o jesuíta intitulado a carta Esperanças de Portugal de Quinto Império do Mundo. Em um outro estudo já expomos que no conteúdo desta carta não há nada de definido a respeito do Quinto Império, nem nos sermões e cartas anteriores ao processo inquisitorial, ou melhor, que os tópicos empregados por Vieira nestes escritos, por nós analisados, são formas infinitae da ortodoxia católica da qual a doutrina do Quinto Império também faria parte, ${ }^{1}$ no entanto, em uma dimensão finita, provavelmente, com circunstância específica de particularização; nos autos o inquisidor pergunta a Vieira em que livros leu a quantidade de impérios existentes no mundo e acerca da existência de algum outro; quando 
há de principiar o dito império e qual será a sua duração. Na admoestação, após serem dadas respostas às questôes, o inquisidor adverte Vieira de que o Quinto Império é contra a doutrina dos Santos Padres e à fé Católica, ao que jesuíta responde:

(...) que nem lhe passou que o intitular o dito papel por "Quinto império do mundo" era contra a Sagrada Escritura, nem contra a comum doutrina dos Santos Padres como ainda lhe parece mostrará mais largamente quando se lhe der tempo para usar de sua defesa. ${ }^{2}$

Como se sabe, foi dado o direito de defesa a Vieira e, logo no primeiro capítulo do que comporia a sua defesa, declara que o seu escrito obedeceria religiosamente a todas as regras da história: as leis do estilo, da cronologia e demais circunstâncias:

E porque nós, em tudo o que escrevermos, determinamos, observar religiosa e pontualmente todas as leys da historia, seguindo em estilo claro e que todos possão perceber, a ordem e sucessão das cousas, não nua e secamente, senão vestidas e acompanhadas de suas circunstancias; e porque havemos de distinguir tempos e annos, sinalar provincias e cidades, nomear nações e ainda pessoas (quando o sofrer a materia), por isso, sem ambição nem injuria de ambos os nomes, chamamos a esta narração "historia", e "Historia do Futuro". ${ }^{3}$

Uma questão que nos surge a partir deste trecho consiste em por que Vieira enfatiza os preceitos da história, ou melhor, que o papel que compõe é planeado segundo os critérios da arte da história. Um outro aspecto de um dos nove primeiros interrogatórios dos autos do processo talvez possa contribuir para a nossa reflexão. O inquisidor Alexandre da Silva, mais adiante, na admoestação do $6^{0}$ exame, julga de impossível e de fábulas as proposiçôes de Vieira acerca do advento do Quinto Império, mais propriamente sobre o aparecimento das dez tribos perdidas e sua redução à fé cristã, acrescentando a acusação de misturar, nas pregações e nos papéis que compunha, a Sagrada Escritura com coisas adulatórias, não verdadeiras, e tidas em tão pouca conta, querendo dar aos judeus as esperanças que lhe são caras:

(...) e por querer favorecer aos judeus, principalmente destes Reinos, em seus erros, acreditando-lhes as esperanças das ditas felicidades temporais, com o 
aparecimento dos dez Tribos vindo todos a cavalo em liteiras, e carroças, e sendo introduzidos por el-Rei Dom João ressuscitado ao Sumo Pontífice, parecendo isto em certo modo, uma novela imaginada. ${ }^{4}$

Deixemos por ora estes dois aspectos dos autos e enveredemos pelos textos que compõem a História do Futuro. Neste primeiro momento, tencionamos discutir elementos compósitos dela, ou seja, a possibilidade de haver aspectos dos exames dos autos que direcionariam a contradita, que Vieira pediu e prometeu entregar como sua defesa diante do libelo acusatório, a seguir o modelo da historiografia.

Tomemos primeiramente a matéria de desempenho da História do Futuro e do Livro Anteprimeiro, que, ao observarmos os autos do processo, principalmente, ao já mencionado $3^{\underline{0}}$ exame, é estabelecido como causa de todo o processo: o Quinto Império, ou seja, a instauração de um império em virtude da queda de outros que o antecederam. Descrevamos, por ora, como Vieira demonstra a futura instauração da dita Quinta Monarquia.

Como já sabemos, o Quinto Império do mundo está no futuro, mas, para que chegue a tal império, será necessário relatar o que foi antes dele; quando se inicia o primeiro livro de sua História do Futuro há a noção de que os impérios e os imperadores se sucedem em uma ordem coercitiva:

Havendo, pois, ainda nesta nossa idade tantos Impérios, e sendo tantos mais os de naçôes bárbaras e políticas que em diversos tempos do Mundo se têm levantado e caído, com razão se deve duvidar e desejar saber a causa por que este nosso Império que prometemos recebe o número de Quinto, e quais sejam, em ordem os outros quatro que lhe deram este lugar ou este nome (...) sem fazer caso de muitos e grandes impérios que floresceram e haviam de florescer em vários tempos e lugares do Mundo, só trata do primeiro que se começou e levantou nele, e dos que em continuada sucessão se lhe foram seguindo até o ponto presente, os quais em espaço quase de quatro mil anos têm sido com este quatro. ${ }^{5}$

No capítulo seguinte da História, Vieira descreve a sucessão dos homens e reinos que conduz toda a história. Inicia no ano de 1860 antes da criação e 3800 anos antes de 1664, depois da dispersão dos povos na dissolução por Deus da empresa da Torre de Babel. Dividiram-se, pois, os povos em reinos e nações. Portanto, deu-se início à tirania, introduzida no 
mundo por Belo, filho de Nembrot. Seguiu-se a eles o império dos Assírios ou Babilônicos, cujo número de imperadores, antes de sua queda com Sardanápalo, foi de 37 monarcas. Posteriormente, elevou-se o império dos persas; teve duração de 230 anos, divididos por 14 imperadores. Subseqüente, foi o império dos gregos com Alexandre, geograficamente, dividido e espalhado entre Ásia, Macedônia e Egito. Finalmente, ergue-se, após o grego, o poderoso Império Romano, cuja duração, entre Júlio César e o cristianíssimo Constantino, é de 400 anos, persistindo como império romano cristão na Alemanha de Fernando III.

Após demonstrar os impérios que foram anteriores ao Quinto Império, Vieira segue, interpretando, como declarou, pelos lugares da Sagrada Escritura, de que modo se dará o advento desta Quinta Monarquia. O texto é do profeta Daniel, em que consta a interpretação que o mesmo profeta fizera de "um sonho que Deus dera" ao rei babilônico Nabucodonosor. Nele, havia uma estátua constituída por membro dos mais diversos materiais: "a cabeça de ouro, o peito, e os braços de prata, o ventre e os joelhos de ferro, os pés de ferro e de barro". ${ }^{6}$ Porém, não obstante a solidez de tal estátua, uma pedra arrancada de um monte a desfizera. Significava a mesma estátua a sucessão do Império do Mundo com seus diferentes reinos; diga-se os quatro impérios que antecederam o Quinto: Assírio, Persa, Grego e Romano. A pedra significava a Quinta Monarquia que suplantaria todos os outros anteriores:

Este Império os há-de desfazer e aniquilar a todos, e ele só há de permanecer para sempre, sem haver de vir jamais por acontecimento algum a domínio ou poder estranho, nem haver de ser conquistado, dissipado ou destruído, como sucedeu ou há-de suceder aos demais. ${ }^{7}$

No capítulo seguinte, para mostrar como seria esta Quinta Monarquia, é interpretada uma segunda profecia de Daniel, ou melhor, uma visão, em que aparecem ao profeta figuras monstruosas, as bestas; uma como leoa com asas de águia que subia da terra; a outra semelhante a um urso que subia do mar; uma terceira, semelhante a um leopardo, com quatro asas e quatro cabeças; e finalmente, uma quarta, muito mais horrível e pavorosa que as anteriores. Seguindo a explicação que o mesmo Daniel dá a sua visão, Vieira diz que estas quatro bestas significam aqueles quatro 
impérios, que sucessivamente haviam de levantar no mundo, mas também sucessivamente derrubadas por determinação divina depois dos quais havia de levantar o Quinto. Assim é concluído o capítulo:

Da mesma maneira a duração da estátua dos impérios era composta de diferentes idades. A sua primeira idade, que é o tempo dos Assírios, foi idade de ouro, a segunda, que é o tempo dos Persas, foi idade de prata, a terceira, que é o tempo dos gregos, foi idade de bronze, a quarta, que é o Império dos Romanos, foi idade de ferro, a quinta, que é este último tempo dos mesmos Romanos, é idade de ferro e de barro. E basta que nesta última idade, como decrépita, daquela estátua ou daqueles Reinos se haja de levantar o Quinto Império... ${ }^{8}$

A mesma causa, a de que o Quinto Império há de ser futuro, é provada com uma profecia de Zacarias, não com as mesmas figuras que foram mostradas a Daniel, mas quatro carroças puxadas por quatro cavalos, melados, murzelos, pombos e remendados, ou seja, ruivos, negros, brancos e vários, entre todos, os mais fortes. Vieira dispõe a interpretação desta visão do profeta da seguinte maneira:

(...) estas carroças significam os mesmos quatro Impérios que Deus mostrou a Daniel, e foram estes Impérios representados ao Profeta em figura de carroças, e declarados pelo Anjo em metáfora de ventos, para mostrar a violência com que seus fundadores conquistariam e sujeitariam por suas armas os reinos, terras e gentes de que se haviam de formar os ditos Impérios; porque, ao uso daqueles tempos, a principal força dos exércitos consistia nas carroças armadas, que eram as que faziam maior estrago na guerra, como se vê nos casos tão celebrados. ${ }^{?}$

É evidente, portanto, que a causa da História do Futuro é relatar as circunstâncias da instauração de um império assim como relataram os historiadores antigos que o mesmo Vieira enumera no Livro Anteprimeiro, porém, com uma diferença: enquanto aqueles da Antigüidade escreveram histórias do passado, a sua história relataria o futuro:

Não escrevemos com Beroso as antiguidades dos Assyrios, nem com Xenophonte as dos Persas, nem com Herodoto as dos Egypcios, nem com Josepho as dos Hebreos, nem com Curcio as dos Macedonios, nem com Tucidides as dos Gregos, nem com Livio as do Romanos, nem com os escri- 
tores Portugueses as nossas, mas escrevemos sem author o que nenhum delles escreveo nem pòde escrever. Elles escrevèrão historias do passado para os futuros, nós escrevemos a do futuro para os presentes. ${ }^{10}$

Não tivemos acesso a uma preceptiva de história nos séculos XVI e XVII, mas a uma da Antigüidade Grega cujo autor foi muito traduzido e lido pelos humanistas, que teve divulgação na Europa Quinhentista principalmente pelas traduções de Erasmo de Rotterdam: Luciano de Samosata. ${ }^{11}$ Portanto, possivelmente, a Arte Histórica de Luciano também, juntamente com a retórica, serviu de preceito para a prática historiográfica desses dois séculos que mencionamos. Nela, Luciano, em um tom meio que zombeteiro, ridiculariza o modo como alguns historiadores se entregavam ao ofício de escrever histórias, observando que, como uma febre, não havia pessoa, que não se punha à pena a tal prática e que, para tal cópia de historiadores, o fato de haver guerras era a causa. Todavia, a despeito desse tom de zombaria, Luciano sublinha que o seu texto servirá, apontando os principais defeitos dos historiadores que ridiculariza, para aconselhar alguns pequenos preceitos para aqueles que escrevem história. ${ }^{12}$ Mesmo que em espécie de tirada, o que salienta Luciano, em um primeiro momento, é o fato de que os historiadores escrevem sobre guerras, sobre reinos que se sucedem. Assim são os historiadores que tanto Dionísio de Halicarnasso, ${ }^{13}$ quanto o próprio Luciano admiram como bons historiadores. Uma análise exaustiva dos historiadores da Antigüidade, bem como da Idade Moderna, não é o intuito deste nosso trabalho, pois não é sua proposta, nem há tempo suficiente para a execução de tal análise; porém, consideramos, para efeito de destacar a diferença que sublinha Vieira haver entre a sua história e as obras dos demais historiadores do passado e do presente, oportuno transcrever, parafrasear ou, somente, mencionar, alguns trechos delas.

Heródoto, convencionalmente, o pai da história, inicia a sua História, ressaltando que, por meio de suas próprias pesquisas e opiniōes, intentou descobrir os motivos da guerra entre os persas e os helenos. Para tal tarefa, lança mão de testemunhos, principalmente relatos dos dois lados beligerantes, mas também, mencionando grandes e pequenas cidades, e os homens, cujas proporçôes, se pequenas, se desmesuradas, demonstram a instabilidade da prosperidade humana. ${ }^{14}$ Quer dizer, para Heródoto, exis- 
tiria um processo cíclico de compensação justa; não haveria nada de humano que fosse estável: o pequeno tornar-se-ia grande e vice-versa; o sentido de um progresso histórico linear não possuía lugar. Reinos desabam e são erguidos, em meio às guerras, porque os homens exacerbados em sua potência erram em desejar ser deuses, a hybris, ou o orgulho desmedido. Esse erro seria punido pelos deuses, pois o mundo responderia a uma ordem (Kósmos), que deveria ser mantida. ${ }^{15}$

Como descrevemos, na História do Futuro de Vieira, o prognóstico do advento do Quinto Império é dado pelas quedas sucessivas de reinos, no entanto, em um sentido diferente das sucessóes que podemos observar na História de Heródoto. Simplesmente, em um primeiro momento, o que diferencia as duas histórias é o que já destacamos por meio de palavras do próprio Vieira: Heródoto é historiador do passado e Vieira caracteriza-se como historiador do porvir. Observa Adma Muhana que foi impossível aos gregos antigos e latinos formularem uma história que relatasse as coisas do futuro, pois as preceptivas e a sua própria concepção de história não permitiam tal narração; por exemplo, a ridicularização que Luciano faz de uma certa história profética:

Tambem ouvi a hum, que escreveo Historia dos successos futuros... portando-se muy ao profeta hia a toda a pressa jà pelo fim da Historia. E de mais tem edificado já na Mesopotamia huma Cidade de extraordinaria grandeza, e de fermosura rara. Ainda porèm anda especulando, e tomando conselho, se será melhor chamarlhe Nicèa, por occasiaô da vitoria, ou Homonèa, ou Irenia... Tambem promettia escrever jà, e logo os futuros successos da India, e a navegaçaõ em torno do mar exterior. E isto naô he só promessa; antes o Proemio, e o terceiro livro da Historia Indica já esta corrente. ${ }^{16}$

Para Luciano, história não é profecia. Vieira, ao contrário, herdeiro de uma já antiga tradição cristã, conhecia na interpretação tipológica a possibilidade de fazer de cada profecia que viesse interpretar parte indivisa do plano global determinado pela Providência Divina para o cumprimento da história. ${ }^{17} \mathrm{~A}$ intervenção divina nos negócios do mundo é o centro a partir de onde se interpreta o passado, projetando-o no futuro e fazendo da história uma narração semelhante à profecia. ${ }^{18}$ Nesse sentido, a história estabelece-se, assim como em Heródoto, como já vimos, uma repetição, 
porém determinada pela Providência, "subordinada à finitude do tempo, teologicamente definido como qualidade análoga da infinitude divina”. ${ }^{19}$ Para Margarida Vieira Mendes, a marcação da cronologia em idades e impérios era um postulado antigo, principalmente, segundo a autora, no simbolismo do número quatro fixado pelos exegetas medievais, do qual Vieira também se utilizava a fim de evidenciar a história como uma totalidade finita. ${ }^{20}$

Essa observação da autora é evidente na História do Futuro, todavia, em data anterior à composição efetiva da mesma, no Sermão da Primeira Dominga do Advento de 1651, sob o evangelho Caelum et terra transibunt: verba mea non transibunt, Vieira se dispõe a contar a história do mundo em todas as suas formas e fases, porque está sempre "passando". Parte de Adão e Eva, que tiveram de mudar do Paraíso Terreal para um mundo de misérias, porque pela garganta de Adão passou a fruta proibida. A partir daí, outras mudanças tiveram este ato de Adão como causa, pois o mundo muda porque os homens mudam; porque se mudam as roupas, as línguas, as leis; misturam-se os sangues; os homens mudam para outras terras, para outros climas. Vieira compila uma série de elementos relacionados aos grandes feitos dos humanos, sentenciando que, por mais excelentes que fossem, um dia acabariam. Fala dos maiores impérios, dos mais poderosos deuses (Saturno, Júpiter, Marte e outros), das mais conhecidas guerras e guerreiros, dos mais famosos jogos, que recebiam desnecessariamente a designação de passatempos, já que o tempo por si próprio passaria. A própria Olimpíada, que para os gregos era o tempo, acabou; as fábulas, por não serem (verdade), não poderiam acabar, mas o tempo e as pessoas que nelas acreditaram, passaram. Uma outra coisa que não poderia acabar, por ter sido formada pelo próprio Deus, mas que de certa forma acabou, foi a nação israelita, que muitas vezes fora vencida e cativa de outros povos. Após falar sobre os homens, Vieira diz que mesmo as grandes construções (as sete maravilhas do mundo antigo) e as grandes cidades (Nínive, Tróia, Cartago), que aparentemente eram inabaláveis, ruíram:

A terra compomse de Reynos, os Reynos compomse de Cidades, as Cidades compomse de casas e campos, e principalmente de homens, e tudo isto, que tudo he terra (e toda a terra) perpetuamente está passando. ${ }^{21}$ 
Se na História, a sucessão dos reinos vale para provar o advento do Quinto Império, num sentido tipológico, muito mais que tropológico ou histórico, no sermão, a mesma sucessão vale para somente provar a instabilidade dos mesmos reinos; um sentido apenas histórico e tropológico: ${ }^{22}$

E sendo todos iguaes, \& livres por natureza, houve alguns que entraraõ em pensamento de se fazer senhores dos outros por viol?cia, \& o conseguiraõ. O primeiro que se atreveo a pôr coroa na cabeça, foy Membroth, que tambem com o nome de Nino, ou Belo deo principio aos quatro Imperios, ou Monarchias do mundo. O primeiro foi o dos Assyrios, \& Chaldeos: \& onde està o Imperio Chaldaico? O segundo foi o dos Persas: \& onde esta o Imperio Persiano? O terceiro foi o dos Gregos: \& onde està o Imperio Grego? O quarto, \& maior de todos foi o dos Romanos: \& onde está o Imperio Romano? Se algua cousa permanece deste, he só o nome: todos passáraô, porque tudo passa. ${ }^{23}$

Logo depois, temos a visão de Nabucodonosor e as profecias de Daniel e Zacarias:

Em tres famosas visoens representou Deos estes mesmos Imperios a hum Rey, \& a dous Profetas. A primeira visão foi a Nabucodonosor na Estatua de quatro metaes: a segunda a Zacharias em quatro carroças de cavallos de diferentes cores: a terceira a Daniel em hum conflicto dos quatro ventos principaes, que no meyo do mar se davão batalha. Pois se todas estas visoens eraô de Deos; \& todas representavão os mesmos Imperios, porque variou tanto a Sabedoria divina as figuras, \& sobre a primeira da Estatua tão clara, $\&$ manifesta acrecentou outras duas taõ diversas em tudo? Porque a Estatua na dureza dos metaes de que era composta, $\&$ no mesmo nome de Estatua, parece que representava estabilidade, $\&$ firmeza: $\&$ porque nenhum daquelles Imperios havia de perseverar firme, \& estavel, mas todos se haviaõ de mudar successivamente, $\&$ ir passando de huas nações a outras; por isso os tornou a representar na variedade das carroças; na inconstancia das rodas, \& na carreira, \& velocidade dos cavallos. Mas naô parou aqui a energia da representação, como naô encarecida ainda bastantemente. A Estatua estava em pè, $\&$ as carroças podiaô estar paradas. E porque aquelles Imperios correndo mais precipitadamente que à redea solta, naô haviaõ de parar no mesmo passo, nem por hum só momento, \& sempre se haviaõ de parar no mesmo passo, nem por hum só momento, \& sempre se haviaó de ir mudando, \& passando; por isso finalmente os representou Deos na cousa mais 
inquieta, mudavel, \& instavel, quaes são os ventos, \& muito mais quando embravecidos, \& furiosos. ${ }^{24}$

Não podemos afirmar se esta invenção do sermão é a mesma com que Vieira pregou o sermão no ano de 1651, ou se foi acrescida quando da revisão dos sermões que se deu efetivamente após o processo inquisitorial. Possivelmente, poder-se-á resolver esta questão examinando folhetos ou os manuscritos do mesmo sermão. Por ora, reafirmamos que a noção da história como signo e efeito da Causa Primeira e também da Causa Final está presente nos dois discursos como método exegético de Vieira, no entanto em um sentido tipológico na História do Futuro, em que os sucessos antigos e contemporâneos são concordados como prenúncio dos futuros contingentes; $;^{25}$ e tropológico, sem uma finalidade, digamos, escatológica, no Sermão da Primeira Dominga do Advento, apenas como exortação que desengana a vanitas. ${ }^{26}$

Entende-se, então, em um primeiro momento, que a noção de história para Vieira é providencialista, em que todos os acontecimentos relevantes aparecem representados por um universo sacralizado, marcados pela Providência Divina. ${ }^{27}$ Ora, se a proposição que move a composição da História do Futuro e do seu Livro Anteprimeiro é a questão do Quinto Império, defini-lo, no sentido histórico e profético que exige, ou melhor, que existira desde sempre, determinado pela Providência para se estabelecer próximo aos tempos últimos, somente seria possível nos moldes de uma história universal. Entendemos, pois, que, possivelmente, este é um dos sentidos que explicaria "observar religiosa e pontualmente todas as leys da historia, seguindo em estilo claro e que todos possão perceber, a ordem e sucessão das cousas" ${ }^{28}$

Na preceptiva de Luciano, não encontramos menção a respeito de uma oposição entre história parcial e história geral; centra os seus exemplos do bem escrever história no trio grego Heródoto, Tucídides ${ }^{29}$ e Xenofonte, ${ }^{30}$ que narraram guerras específicas entre povos, ou melhor, entre dois povos, e dos quais todos os outros posteriores historiadores seriam imitadores. ${ }^{31}$ Porém lemos tal oposição no historiador grego Políbios, que viveu em torno do século II antes de Cristo, cuja História aponta, de maneira incisiva, os elementos que constituem a história como uma arte com suas utilida- 
des. O tema de sua História apóia-se em examinar como no decurso de cinqüenta e três anos os romanos conseguiram submeter o mundo ao seu domínio, o que, segundo o historiador, nunca na história humana havia acontecido. Assim como os historiadores anteriores a ele, Políbios diz que colocará lado a lado os impérios mais famosos do passado, para que se possa compará-los com o império dos romanos e evidenciar como em um dado momento a história passa a ter um todo orgânico, no sentido de que dois povos, os romanos e os cartagineses, estavam organizados a ponto de conceberem um império em escala mundial. Por isso, diz Políbios, a História tem início em um período anterior à instauração do império romano, a primeira expedição marítima, na $129^{a}$ Olimpíada, mas também, porque os helenos, como lhes é característico, desconhecem a história. ${ }^{32}$

Políbios considera que sua história traz uma novidade que as outras histórias não levavam em consideração: a importância da história geral em relação às histórias parciais. Diz que, tendo o Fato encaminhado os acontecimentos mundiais em uma única direção, ele, como historiador, foi obrigado a orientar todos os eventos do mundo para a história de Roma:

Com efeito, a originalidade de minha obra e o aspecto de minha obra mais notável de nossa época consistem justamente nisto: a Sorte encaminhou por assim dizer todos os acontecimentos mundiais em uma única direção e os compeliu a orientar-se para um só e mesmo escopo; da mesma forma, um historiador deve apresentar diante de seus leitores em uma sinopse os eventos graças aos quais a Sorte produziu esses efeitos em toda parte para atingir o seu objetivo global. ${ }^{33}$

No discurso de Políbios, é o Fato, sempre de forma irracional, que conduz os eventos da história do mundo para um fim específico, sendo papel do historiador investigar e descrever de que forma estes fatos se relacionam a ponto de convergirem em uma única direção. Antes, porém, de relatar este fim no qual o Fato convergiu todos os eventos, preceitua o historiador, é necessário remontar os eventos que o antecederam, tal como um preâmbulo a toda a história que se vai narrar:

Como este período antecede imediatamente a época cuja história vou escrever, pensei que seria útil, ou melhor, que o plano da obra me impunha, expor com clareza a todos os leitores a situação dos macedônios e dos helenos 
“Leys da história”, “estilo Claro”, “ordem e sucessão das cousas” • 93

nesse período (...) Completei assim esta introdução ou preâmbulo a toda a minha História. Nela mostrei inicialmente quando, como e por que os romanos, dominada a Itália, decidiram-se pela primeira vez a cometimentos fora de sua terra e disputaram o domínio do mar com os cartagineses. ${ }^{34}$

É possível que a noção de história geral tenha sido apropriada pelo cristianismo, porque, como rapidamente já temos descrito, o mundo, o tempo e a história têm sua causa e fim na Providência Divina, assim, de certa forma, todos os acontecimentos, mesmo que sendo primeira ou segunda causas convergiriam para o Ser. ${ }^{35}$ Somente para um fim ilustrativo, mencionemos a Crônica Geral da Espanha que inicia sua narrativa em como Moisés escreveu a respeito do dilúvio no Gênesis, como início natural dos eventos da história espanhola como nação cristã, eleita por Deus. ${ }^{36}$ Outro exemplo dessa reconstrução do passado, como sendo eventos que convergem para um fim específico, no caso para a eleição da nação que completa o reino Deus em sua esfera terrena, opera-se de forma monumental na Monarquia Lusitana. No Prólogo da primeira parte, Frei Bernardo de Brito, como que emulando Políbios diz:

E como isso não podia ser [escrever a história de Portugal], sem renovar o trabalho de principio, não quis q me saisse das maôs sem algu fruito: \& tomando neste particular o parecer de pessoas califficadas, me acôselharão, q juto cô a historia Portuguesa, fizesse pella orde dos annos, hu Epelligo géral das cousas do mundo, pera q os Portugueses, satisfizess? cố a lição desta historia, a grãde falta q t? de rellações antigas, $\&$ servisse este modo de os affeçoar mais ás cousas de seus antepassados, quando á vista das do mundo lhe conhecessem tão notoria ventagem. ${ }^{37}$

Alguns estudiosos verificaram o sentido universalizante da História do Futuro e de seu Livro Anteprimeiro, enfatizando a questão dos interlocutores e também o sentido da história como totalidade finita. Adma Muhana afirma:

Todos estes elementos - a predominância dos exemplos como provas intrínsecas; a oscilação entre a garantia do passado e a proposta do futuro (aprofundada pela noção de tipo); o modelo historiográfico seguido; uma amplitude de destinatários em que estes são virtualmente chamados a agir; um direcionamento pedagógico fundado em conselhos e advertências; um des- 
taque para os bens e utilidades que advirão se forem assumidos os comportamentos - todos estes elementos, dizíamos, próprios da invenção do gênero deliberativo, levou-nos a privilegiar na análise da História do Futuro a sua proximidade com os discursos deste gênero. ${ }^{38}$

Observando a História a partir dos autos, tomemos inversamente as consideraçôes da autora, sublinhando que a causa da História do Futuro, enquanto composição discursiva, estaria prioritariamente na proposição, como causa, do Quinto Império que os inquisidores censuram a partir do título da Carta e não na deliberação enquanto base de decisões políticas, político-teológicas no caso do Seiscentos. No decorrer dos interrogatórios, como também já sabemos, sobre as proposições que se censuraram na Car$t a$, questiona-se Vieira a respeito das circunstâncias que precederão e envolverão o Quinto Império, sendo elas, portanto, cada vez mais definidas, como, por exemplo, o lugar em que se estabelecerá o dito império: Portugal. Portanto se o fim da História do Futuro é narrar os eventos que consolidarão o Quinto Império em terras e reino lusitano, seguindo os preceitos da história geral, como aqueles que evidenciamos na História de Políbios, ou no Prólogo da Monarquia Lusitana, é necessário contar o início da história humana na forma como os eventos que o constituem contribuem para o estabelecimento do Quinto Império em solo português. Por isso a necessidade de um Livro Anteprimeiro, como um preâmbulo. Portanto consideramos que a erudição das citações da mitologia greco-romana, antes que satisfazer um público culto, como afirma Adma Muhana, ${ }^{39}$ presta-se bem mais a reconstituir estes precedentes. $\mathrm{O}$ caráter universalizante, que incorpora, conseqüentemente, um amplo auditório, se dá justamente pela necessidade de se fazer uma história universal, tendo em vista a proposição que a condiciona. Portanto consideramos que a amplitude de referências, a que a mesma autora, cuja obra vimos acompanhando em nossa análise, denomina "universalismo cultural", ${ }^{40}$ não estaria destinada ao auditório diretamente, mas à composição da própria obra, ou melhor, a própria causa dela.

Seria neste aspecto, então, que no primeiro capítulo do Livro Anteprimeiro Vieira faz um retrospecto das formas que no decorrer dos tempos o homem intentou formular ciências para conhecer o futuro. O primeiro modo foi os oráculos que inauguraram no mundo a idolatria da gentilidade, como as consultas feitas ao ídolo de Apolo em Delfos, o de 
Júpiter em Babilônia, o de Juno em Cartago, o de Vênus no Egito, o de Dafne em Antioquia, o de Orfeu em Lesbos, o de Fauno na Itália, o de Hércules na Espanha entre outros. Posteriormente, vieram as ciências, ou ignorâncias, como quer Vieira, das artes ou superstiçōes inventadas a partir dos quatro elementos que estão dispostos entre o céu e a terra: a geomancia, que entrevê o futuro pelas coisas da terra; a hidromancia, pelas da água; a aeromancia pelas do ar; e a piromancia pelas do fogo. Temos ainda aquelas ciências ou artes do futuro que os homens tiraram de seu próprio corpo, como mapa: a fisionomia e a quiromancia. Abstém-se, por motivos óbvios, de falar da astrologia judiciária e da funesta nigromancia, cujo meio de vislumbrar o porvir baseia-se, no segredo da noite, em invocar aos mortos das sepulturas. Espalharam-se de tal forma as superstiçōes sobre os meios de se conhecer o futuro, que os homens passaram a pedir resposta para o segredo de seu destino nas entranhas palpitantes dos animais, aos rios, às arvores, ao vôo das aves, ao mugido dos animais, aos números, aos nomes, às letras, aos dias, aos fumos, às sombras, às cores, enfim, em tudo viam os avisos da Providência. Conclui o panorama pelo modo como o homem, nas mais diversas idades do mundo, desejou aplacar o seu apetite em conhecer as coisas do futuro, em como ele tornou-se motivo de investigação dos mais insignes filósofos e filosofias. ${ }^{41}$

Da mesma forma, como já mencionamos, Vieira afirma que os homens também escreveram histórias, porém estas se limitaram a relatar eventos passados e presentes, sendo incapazes de narrar os eventos do porvir. Aqui, séculos depois, parece que é Vieira que zomba de Luciano, a respeito do que o autor grego critica nas histórias ditas proféticas: ${ }^{42}$

Impossivel pintura parece, antes dos originaes, retratar as copias, mas isto he o que fará o pincel da nossa Historia. Assim foraô retratos de Christo Abel, Isac, Joseph, David, antes do Verbo ser homem. O que ignorou o mundo antigo, o que naố conheceo o moderno e o que não alcança o presente, he o que se verá com admiração neste prodigioso mappa descrito: cousas e casos, que ainda lhe falta muyto para terem ser, quanto mais antiguidade. ${ }^{43}$

Aqui, retomemos aquele outro aspecto dos autos que mencionamos no início deste trabalho, em que o inquisidor Alexandre da Silva acusa Vieira 
de proferir e anunciar fatos não verdadeiros, principalmente a ressurreição de D.João IV e o aparecimento das dez tribos perdidas de Israel e sua redução ao cristianismo como contingências para a instauração do Quinto Império; considerando tais contingências adulação aos judeus, fábulas e novela imaginada. O capítulo sexto do segundo livro da História do Futuro em que continua a matéria que propõe que o Reino e Império de Cristo é também temporal, pois o mesmo Cristo é aceito e eleito por todas as nações do mundo, afirma Vieira que Deus dispersou a nação hebréia pelo mundo para que nele se perdessem, propagassem e dilatassem suas esperanças e doutrina, fosse por meio do comércio, fosse por meio do desterro. Por isso todas as nações, tanto gentílicas quanto a nação hebréia, sempre expectaram e anunciaram a vinda do messias. Adiante, Vieira diz que a Providência de Deus dispôs nas Sagradas Escrituras variedade de maravilhas e de coisas notáveis para que os gentios acostumados aos discursos fabulosos pudessem persuadir-se da fé de Deus e das Esperanças de Cristo, sendo assim convertidos ao seu domínio. Para Vieira, porque estiveram misturados ao povo hebreu, tudo o que se tem por fábula dos gentios é imitação do que Deus escreveu em seus sagrados livros. Esta afirmação tem evidentemente o sentido com que Santo Agostinho qualificou o pensamento dos autores anteriores ao Cristianismo: ${ }^{44}$

Quem quiser saber facilmente quão estudadas eram dos Gentios as Escrituras, leia com atenção os livros dos seus filósofos, dos seus historiadores e ainda dos seus poetas, e verá o que delas tomaram, dela imitaram e sobre elas fingiram; verá quanto as não largavam das mãos. "Tudo o que compôs o estilo dos vossos escritores - dizia Tertuliano aos Gentios - a substância, a matéria, a origem, a ordem, as histórias das gentes e das cidades insignes, e ainda as mesmas cidades e algumas das gentes; as causas e memórias do que escreveram e até a forma das letras e imagens dos caracteres, e os vossos mesmos deuses (e não digo nisto mais senão menos) os vossos templos, os vossos oráculos, os vossos sacrifícios, tudo vencem em muitos séculos de antiguidade os livros de nossas profecias, e tudo foi tomado do tesouro das escrituras judaicas, que são também as nossas". ${ }^{4}$

Antes de prosseguirmos a demonstração de Vieira (que possivelmente é uma resposta ao inquisidor Alexandre da Silva, provando que suas coisas profetizadas correspondem ao curso natural da Providência rumo à instau- 
ração do Quinto Império e não coisas inventadas, inverossímeis e quiméricas) vejamos, rapidamente, como a história se oporia aos discursos ditos fabulosos e adulatórios. ${ }^{46}$ Genericamente, como podemos observar nos preceitos de Luciano, a história será tida como aquela que não comporta a falsidade, ou seja, busca sempre a verdade, por isso sua definição se dá por oposição a tudo o que não seja a verdade: o verossímil, o falso, o impossível e o que ainda não aconteceu, ou seja, a poesia, a adulação, a fábula, a profecia, já mencionada. É desta forma que o mesmo Luciano preceitua o modo de bem escrever história. A poesia seguiria uma liberdade, cuja lei seria somente o pensamento do poeta, que em sua obra poderia mencionar elogios diversos e aspectos fabulosos para o deleite do auditório. ${ }^{47}$ Disso deve estar precavido o historiador, pois o que se requer dele é a inteligência política e o conhecimento das coisas que relata, ${ }^{48}$ talvez, pensamos, seja por este preceito que Luciano censura as ditas histórias proféticas, pois não se poderia narrar o que ainda não teve lugar nos particulares sucedidos da história, ou seja, o futuro.

Nas palavras de Vieira, as fábulas descrevem o Dilúvio, mas não tiveram fantasia de colocar todo o mundo em uma arca como o fez Noé; nenhum poeta ousou traçar uma comédia como a de Jó, uma tragédia como a de Amã, uma novela ou enredo como a de José; não houve no mundo dos gentios teatro que pudesse representar as aparências de tanto artifício de um Paraíso Terreal sumido no meio do Mundo, um Enoque que trasladado por Deus, não viu a morte, outros que foram tragados pela terra, ou Elias que voou pelos ares em um carro de quatro cavalos, todo de fogo, os cavalos e as rodas. ${ }^{49}$ Todo este capítulo, como já sublinhamos, possivelmente, seria uma resposta a Alexandre da Silva, em que Vieira contra-argumenta a afirmação de que a interpretação que faz das coisas de Deus é fábula, novela a adulação aos judeus, dizendo que a direção é inversa: não poderia ter a Providência de Deus aparência das fábulas inventadas pelos homens, pois elas são cópias da mesma Providência. Neste sentido, o Quinto Império e os eventos que o circundam seriam o original, enquanto os eventos humanos relatados pelos historiadores e poetas do passado, que os antecederam, as cópias.

Como afirma Margarida Vieira Mendes, é o conhecimento das coisas que se vai narrar, como observamos preceituado em Luciano, que dá a Vieira 
a possibilidade de avançar no tempo e relatar no presente as coisas que estão para acontecer no futuro, ${ }^{50}$ ou seja, a interpretação da cópia que prefigura o original, tipologia por excelência. Coisas que aparentavam ser fabulosas, não credíveis, ou inverossímeis sempre estiveram presentes nas Sagradas Escrituras, como o mesmo Vieira afirma, no entanto são prefigurações de fatos que na história se concretizam. Agregando assim fatos que circunscrevem o mito cosmogônico do Velho Testamento, como a Criação, o Dilúvio, a Arca de Noé, a Torre de Babel e dos primeiros homens como Adão e Eva, Nemrod, Abraão, Saul, bem como dos eventos e personagens das "histórias humanas do passado e do presente", como Tubal, no caso da história mítica de Portugal, ${ }^{51}$ Vieira os interpreta, na composição da História do Futuro, com o sentido de demonstrar a instauração próxima do Quinto Império. Assim, segundo a mesma autora, são interpretados os Descobrimentos, mais especificamente o episódio da travessia do Cabo do Não. No Livro Anteprimeiro, eles lembrariam o próprio tema do livro, pois o mapa do mundo até então desconhecido em sua totalidade, pelo feito dos portugueses foi dado a conhecer ao mesmo mundo, quer dizer, o Quinto Império até então encoberto sob a prefiguração dos eventos passados são evidenciados à medida que a Providência os vai concretizando. Atravessar o Cabo do Não antes era impossível, não obstante tal feito estar verbalizado e profetizado nas Escrituras. ${ }^{52}$ Portanto os Descobrimentos, muito mais que exemplos engrandecedores da nação portuguesa, seriam o centro da história do futuro que Vieira narra: resultado dos feitos anteriores a si e fio condutor da concretização da vontade divina: ${ }^{53}$

Portentosas forão antigamente aquellas façanhas, oh Portugueses, com que descubristes novos mares e novas terras, e déstes a conhecer o mundo ao mesmo mundo. Assim como lieis então aquellas vossas historias, lede agora esta minha, que tambem he toda vossa. Vós descubristes ao mundo o que elle era, e eu vos descubro a vós o que haveis de ser. Em nada he segundo e menor este meu descubrimento, senão mayor em tudo: mayor Gama, mayor Cabo, mayor Esperança, mayor Imperio. Naquelles ditosos tempos (mas menos ditosos que os futuros) nehuma cousa se lia no mundo senão as navegações e conquistas de portugueses. Esta Historia será o silencio de todas as historias. Os inimigos leráó nellas suas ruinas, os emulos suas invejas, e só Portugal suas glorias. Tal he a historia, Portuguezes, que vos presento, e por isso na lingua vossa. ${ }^{54}$ 
Desse modo, a História Universal da Salvação não se restringiria a Jesus e à sua Igreja, mas, por meio da interpretação tipológica, seria prolongada à história de Portugal, ou melhor, a nova realidade inaugurada pelos portugueses, os Descobrimentos, passaria a integrar as figuras bíblicas. ${ }^{55} \mathrm{Da}$ mesma maneira, supomos, o aparecimento das dez tribos perdidas, bem como a efetuação do Quinto Império porque partes da história de Portugal, destarte, figuras das Escrituras, como profecias determinadas pela Providência Divina, teriam sua efetuação na história e no tempo. Neste aspecto, a respeito do que Vieira diz sobre as fábulas do mundo como cópias das obras divinas, o surgimento das ditas tribos não se efetua como imitação, mas como original.

Assim, como dissemos no início deste trabalho, demonstramos alguns elementos da noção de história e da historiografia presentes na História do Futuro e em seu Livro Anteprimeiro, tendo por base dois aspectos dos autos do processo, ou seja, a necessidade de definição do Quinto Império presente no $3^{0}$ exame e o fato de Alexandre da Silva qualificar as proposiçóes de Vieira como fábulas e não como fatos verdadeiros, prognosticados pela profecia. Ainda sobre os interrogatórios, inúmeras vezes os inquisidores acusam Vieira de ir contra o comum acordo dos doutores e a fé católica. Com a proposição do Quinto Império, Vieira interpreta todo o passado, incluindo a patrística antiga e moderna, de forma que todo o seu conteúdo convirja para a instauração da dita monarquia. Nesse sentido, os inquisidores obrigam Vieira a narrar os fatos a partir da Providência, ou melhor, da História Providencial.

Nesse aspecto, se pudermos pensar a questão do Quinto Império como não contínua dentro da obra de Vieira, mas sendo algo que se apresenta em Esperanças de Portugal, sendo forçado à definição pelos autos do processo e conseqüentemente relatado em uma história, os sentidos de Providência e de deliberação, ou melhor, o caminho pelo qual o homem, por sua vontade, deve alcançar o Quinto Império, seria simultâneo à composição da própria obra. Naqueles escritos anteriores, que parte analisamos, em um outro estudo, verificamos o sentido genérico desta deliberação, amparada sim na Providência Divina, porém naquele sentido que encontramos na Monarquia Lusitana, por exemplo, ou na Restauração de Portugal Prodigiosa: Portugal como uma nação cristã, construída por Deus, cuja vocação é administrar e guardar os preceitos de Deus. 


\section{Bibliografia}

AGOSTINHO, Santo. Confissões. Tradução de A. Ambrósio de Pina. São Paulo: Abril Cultural, 1973.

ARISTÓTELES. Poética. Tradução, comentários e índice analítico e onomástico de Eudoro de Souza. São Paulo: Abril Cultural, 1973.

CÍCERO, Marco Túlio. De Inventione. De L'invention. Texte Établi et traduit par G. Achard. Paris: Les Belles Lettres, 1994.

FABRI, Pierre. Le Grand et Vrai Art de Pleine Rhétorique. Publié avec introduction, notes et glossaire par A. Héron. Premier Livre: Rhétorique. Genebra: Slatkine Reprints, 1969.

GAGNEBIN, Jeanne Marie. Sete aulas sobre linguagem, memória e história. Rio de Janeiro: Imago, 1997.

HALICARNASSO, Dionísio. Tratado da Imitação. Editado por Raul Miguel Rosado Fernandes. Lisboa: Instituto nacional de Investigação Científica; Centro de Estudos Clássicos das Universidades de Lisboa, 1986.

HANSEN, João Adolfo. Vieira, tempo, alegoria e história. Brotéria. Lisboa: Oriente - Out/Nov 1997, vol. 145, pp.541-556.

HERÔDOTOS. História. Tradução do grego, introdução e notas de Mário da Gama Kury. Brasília: Editora da Universidade de Brasília, 1985.

LÍVIO, Tito. História Romana. Traducción del latin por Francisco Navarro y Calvo. Buenos Aires: El Ateneo, 1955.

LUCIEN. "Comment il faut écrire l'histoire" in Oeuvres Complétes. Paris: Garnier, s/d. MENDES, Margarida Vieira. A Oratória Barroca de Vieira. Lisboa: Caminho, 1986.

.Vieira no Cabo de Não: os Descobrimentos no Livro Anteprimeiro da História do Futuro. Revista Claro-Escuro, n. ${ }^{\circ}$ 6-7. Lisboa, 1991, pp.9-19.

MUHANA, Adma. A Epopéia em Prosa Seiscentista. São Paulo:Unesp, 1997. . Os Recursos Retóricos na Obra Especulativa de Antônio Vieira. Dissertação de Mestrado em Literatura Brasileira, USP — Serviço de Apoio Didático, 1989.

PÉCORA, Alcir. Teatro do Sacramento. São Paulo; Campinas: Edusp; Editora da Unicamp, 1994. 
POLÍBIOS. História. Seleção, tradução, introdução e notas de Mario da Gama Kury. Brasília: Editora da Universidade de Brasília, 1985.

TUCÍDIDES. História da Guerra do Peloponeso. Tradução do Grego, introdução e notas de Mario da Gama Kury. Brasília: Editora da Universidade de Brasília, 1982.

VIEIRA, Antônio. História do Futuro. Introdução, actualização do texto e notas por Maria Leonor Carvalhão Buescu. Lisboa: Imprensa Nacional — Casa da Moeda, 1992.

. História do Futuro (Livro Anteprimeiro). Edição crítica, prefaciada e comentada por José van den Besselaar. Munster, Aschenforff, 1976, 2 vols. . Sermões. São Paulo: Editora Anchietana Limitada, 1943. 16 vols. VILANOVA, Antonio. Erasmo y Cervantes. Madrid: Editorial Lumen.

\section{Notas}

${ }^{1}$ Os tópicos que compuseram a nossa busca nos sermões e cartas anteriores ao processo agrupam em: Bandarra profeta, a ressurreição de D. João IV, profecia e profeta alumiados pela luz divina, alguns castigos futuros à Igreja, o Turco, a predestinação, judeus e o Império Temporal de Cristo na Terra.

${ }^{2}$ Os Autos do processo de Vieira na Inquisiçãa, p.65.

${ }^{3}$ Livro Anteprimeiro, I, 187-194.

${ }^{4}$ Os Autos do Processo de Vieira na Inquisição, $6^{\circ}$. exame, p.81.

${ }^{5}$ História do Futuro, I, 1.

${ }^{6}$ História do Futuro, L I, 1.

${ }^{7}$ História do Futuro, I, 1.

${ }^{8}$ História do Futuro, L I, 2.

${ }^{9}$ História do Futuro, L I, 3.

${ }^{10}$ Livro Anteprimeiro, I, 115-122.

${ }^{11}$ Antonio Vilanova nos informa esta predileção dos humanistas e, principalmente, de Erasmo por Luciano, quando analisa o tema da vida como comédia na Espanha Quinhentista. Cf. "El tema del gran teatro del mundo in Erasmo y Cervantes, p. 459.

${ }^{12}$ LUCIEN. Comment il faut écrire l'histoire. In Oeuvres Complétes. Paris: Garnier, s/d, pp. 2-3.

${ }^{13}$ Cf. HALICARNASSO, Dionísio. Tratado da Imitação. Editado por Raul Miguel Rosado Fernandes. Lisboa: INIC/ Centro de Estudos Clássicos das Universidades de Lisboa. L II, III, p. 58-59 
${ }^{14}$ HERÔDOTOS. História, L I, 1, 2, 3. Tradução do grego, introdução e notas de Mario da Gama Kury. Brasília: Editora Universidade de Brasília, 1985.

${ }^{15}$ Cf. GAGNEBIN, Jeanne Marie. O início da história e as lágrimas de Tucídides. In Sete aulas sobre linguagem, memória e história. Rio de Janeiro: Imago, 1997, pp.20-21.

${ }^{16}$ LUCIANO. Arte Historica. A partir de uma tradução portuguesa do século XVIII citada pela autora apud A epopéia em prosa seiscentista. São Paulo: Editora da Unesp, 1996, pp.263-264. Na edição francesa das obras completas de Luciano, já citada por nós, encontra-se no parágrafo 31, p.18.

${ }^{17}$ Cf. MUHANA, Adma. Os recursos retóricos na obra especulativa de Antônio Vieira. Dissertação de Mestrado em Literatura Brasileira, USP — Serviço de Apoio Didático, 1989. p. 108.

${ }^{18}$ Idem, p.69.

${ }^{19}$ HANSEN, João Adolfo. Vieira, tempo, alegoria e história. Brotéria. Lisboa: Oriente Out./Nov. 1997, vol. 145, p. 541.

${ }^{20}$ MENDES, Margarida Vieira. A oratória barroca de Vieira, op.cit. pp.521-525.

${ }^{21}$ Sermão da Primeira Dominga do Advento, 1651, IV, 16.

22 Para entendimento destes sentidos da exegese bíblica Cf. HANSEN, João Adolfo. Alegoria: Construção e Interpretação da Metáfora. São Paulo: Atual, 1987, cap.III.

${ }^{23}$ Sermão da Primeira Dominga do Advento, 1651, II, 6.

${ }^{24}$ Idem.

${ }^{25}$ HANSEN, João Adolfo. Vieira, tempo, alegoria e história, op.cit. p. 544.

${ }^{26}$ Cf. PÉCORA, Alcir. Oficina universal, armazém divino. In Teatro do Sacramento. São Paulo; Campinas: Edusp; Editora da Unicamp, 1994, p.160.

${ }^{27}$ MUHANA, Adma. Os recursos retóricos na obra especulativa de Antônio Vieira, op.cit., p.71.

${ }^{28}$ Livro anteprimeiro, I, 187-188.

${ }^{29}$ Tucídides narrou a guerra dos atenienses contra os peloponésios, mas com o fim de verificar se ela era mesma a maior e mais importante de todas as guerras, pesquisando os sinais mais remotos, chegando, no entanto, a evidências de que não fora tão grande. TUCÍDIDES. História da Guerra do Peloponeso, L I, 1. Tradução do Grego, introdução e notas de Mário da Gama Kury. Brasília: Editora Universidade de Brasília, 1982.

${ }^{30}$ Xenofonte, em sua Ciropedia, segue a mesma noção de Heródoto e, por investigação própria, narra o que ouvira de Ciro, o imperador persa. "Refletimos um dia no grande número de estados populares que sucumbem ao poder dos partidos, no grande número dos partidos, no grande número de monarquias de oligarquias que sucumbem ao poder de partidos democráticos, e também no grande número de reis, que tendo usurpado o ceptro, foram uns imediatamente privados dele, outros enquanto o empunharam, foram sempre objecto de admiração por sua sabedoria e felicidade." XENOFONTE, Prólogo in Ciropedia. Tradução João Felix Pereira. Rio de Janeiro: W.M. Jackson INC, s/d, pp.5-7. 
${ }^{31}$ LUCIEN. Comment il faut écrire l'histoire, op.cit., p.2.

32 POLÍBIOS. História. Seleção, tradução, introdução e notas de Mário da Gama Kury. Brasília: Editora Universidade de Brasília, 1985, L I, 1, 2, 3.

${ }^{33}$ História, I, 4.

${ }^{34}$ História, II, 71.

${ }^{35}$ Cf. PÉCORA, Alcir. A razão do mistério. In Teatro do Sacramento, op.cit., pp.111-136.

${ }^{36}$ Crónica General de España, f.3.

${ }^{37}$ Monarquia Lusitana, Prólogo, p.4.

${ }^{38}$ Os recursos retóricos na obra especulativa de Antônio Vieira, III, 4, p. 117 , grifos da autora.

${ }^{39}$ Os Recurso Retóricos na obra especulativa de Antônio Vieira, III, 4, p.112.

${ }^{40}$ Idem, Ibidem.

${ }^{41}$ Cf. Livro Anteprimeiro, I, 5-89.

${ }^{42}$ LUCIEN. "Comment il faut écrire l'histoire", op.cit., p.18.

${ }^{43}$ Livro Anteprimeiro, L I, I, 120-128.

${ }^{44}$ Cf. Confissões, VIII, em que Santo Agostinho afirma, principalmente, que as obras platônicas sugerem, de todos os modos, Deus e o seu Verbo.

${ }^{45}$ História do Futuro, L II, 6.

${ }^{46}$ Aristóteles, na Poética, menciona a história como negativo da poesia; define poesia enquanto a arte do poeta, e a história como o negativo deste gênero de imitação. Não é o ofício do poeta narrar o que aconteceu, e sim o de representar o que poderia ter acontecido, o verossímil. Portanto os ofícios do poeta e do historiador diferem não pela forma, pois as obras de Heródoto poderiam ser postas em verso, não deixando por isso de ser história, e as obras de um poeta, em prosa, não deixando de ser poesia. Ambas diferem, portanto, porque o historiador diz as coisas que sucederam e o poeta canta as coisas que poderiam ter acontecido. Também diferem pela ordem: a história segue uma ordem natural, enquanto a poesia, uma ordem artificial, necessária. A despeito de serem antitéticas, o poeta pode utilizar a história como imitação, pois o que aconteceu, somente o foi, porque era possível. Por isso Aristóteles afirma que a poesia se refere ao universal e, portanto, tem algo de filosófico, enquanto a história se refere ao particular. ARISTÓTELES. Poética. Tradução, comentários e índice analítico e onomástico de Eudoro de Souza. São Paulo: Abril, 1973, cap.XVIII, IX. Cícero, por sua vez, define no De Inventione três aspectos da narração, classificando-a em três tipos: a fábula, que contém elementos que não são verdadeiros, nem verossímeis, como por exemplo, narrativas de dragões alados; o argumento, ou ficção, é um evento criado que poderia acontecer, ou seja, é verossímil: epopéias, tragédias, comédias, ou seja, a poesia; e, por fim, a história, em que se contam os eventos que aconteceram em algum lugar, em uma época distante de quem narra: as grandes guerras da Antigüidade. Cícero vai além de Aristóteles e não só diferencia a história do verossímil, a poesia, como também do impossível, a ficção, ou fábulas. CÍCERO. De Iventione. De L' Invention. Texte établi et traduit par G. Achard. Paris: Belles Lettres, 1994, L I, 27. Tam- 
bém, seguindo Cícero, outro preceptista moderno, o francês Pierre Fabri: "Histoire, c'est de raconter chose vraye et aduenue; vray semblable, c'est de dire chose qui n'a point esté, mais eust bien peu estre; fable, de dire chose qui oncques ne fu ne sera." Le grand e vrai art de pleine rhétorique, p.65.

${ }^{47}$ LUCIEN. Comment il faut écrire l'histoire, op.cit., p.5-6. Segundo o estudo de Jeanne Marie Gagnebin, nas historiai de Heródoto "há uma partilha entre dois tipos de narrativas que correspondem a duas formas de tempo: há uma narrativa mítica, lendária, sem cronologia possível, que remete ao tempo afastado dos deuses e dos homens; e há uma narrativa 'histórica' (de um tempo pesquisável e pesquisado), com referências cronológicas passíveis de serem encontradas, que trata do tempo mais recente dos homens". Ainda segundo a autora, não haveria em Heródoto uma negação do tempo mítico e sagrado, ele ressalta que este tempo realmente existiu, no entanto o que o historiador recusava são os procedimentos narrativos do mito para descrever o tempo humano, restrito, finito e histórico. Cf. "O início da história e as lágrimas de Tucídides”, op.cit., pp. 19-20.

${ }^{48}$ LUCIEN. Comment il faut écrire l'histoire, op.cit., pp.20-21. Ainda, seguindo os passos de Jeanne Marie, em favor deste conhecimento das coisas relatadas, e preocupado com exigências político-jurídicas, Tucídides, quando narra a Guerra do Peloponeso, rejeita o domínio das antigas tradições míticas, pois, devido a seu caráter mnemônico, não possui solidez e se desfaz. Cf. "O início da história e as lágrimas de Tucídides", op.cit., p.26. Um outro historiador, posterior a Tucídides, também pretere, em sua história, os elementos ditos míticos que poderiam se agregados à história. É o caso de Tito Lívio que em sua História Romana ignora o proveito que poderia ter em escrever a história do povo romano desde sua origem, pois sobretudo, quando considera a antiguidade de alguns feitos, aparece, em muitos historiadores, embelezada por fantasias poéticas, apoiada no irrecusável testemunho da história. No entanto, em sua história, não pretendeu rechaçá-las, nem afirmá-las, antes perdoar o hábito da antigüidade de mesclar coisas divinas e humanas que imprime caracteres mais augustos à origem das cidades. Toda a atenção, diz Lívio, de sua história será voltada ao conhecimento da vida e costumes dos primeiros romanos, averiguar quais foram os homens e quais as artes, tanto na paz como na guerra, que fundaram a grandeza de tal império e que lhe deram impulso, e seguir, enfim, com exatidão, a decadência dos mesmos costumes, que o levou à ruína. LÍVIO, Tito. História Romana. Traducción del latin por Francisco Navarro y Calvo. Buenos Aires: El Ateneo, 1955, T.I, pp. 15-17.

${ }^{49}$ História do Futuro, II, 6.

${ }^{50}$ MENDES, Margarida Vieira. Vieira no Cabo de Não: os Descobrimentos no Livro anteprimeiro da História do Futuro. Revista Claro-Escuro, n0 6-7. Lisboa, 1991, p.15.

${ }^{51}$ MENDES, Margarida Vieira. A Oratória Barroca de Vieira, op.cit., capítulo 10, passim.

${ }^{52}$ Idem, "Vieira no Cabo de Não: os Descobrimentos no Livro Anteprimeiro da História do Futuro", op.cit., pp.15-16.

${ }^{53}$ Cf. MUHANA, Adma. Os recursos retóricos na obra especulativa de Antônio Vieira, op.cit., p.74. 
“Leys da história”, “estilo claro”, “ordem e sucessão das cousas” • 105

${ }^{54}$ Livro Anteprimeiro, III, 151-162.

${ }^{55}$ Idem, pp.96-98.

\section{Resumo}

Através de um estudo do Livro Anteprimeiro da História do Futuro - e dos livros que compõem a História do Futuro - épossivel analisarmos os elementos da historiografia nos quais Antonio Vieira estava inserido e talvez encontrarmos pistas do porquê e dos elementos com que a composição de uma história poderia defendê-lo das questóes de que estava sendo acusado na Inquisição.

\section{Abstract}

In the Livro Anteprimeiro da História do Futuro - and also the other books that compose the História do Futuro - it is possible to analyze the elements of the historiography in which Antonio Vieira was inserted and maybe we can find clues of the reasons of using history and its elements as a way of defense during the Inquisition. 